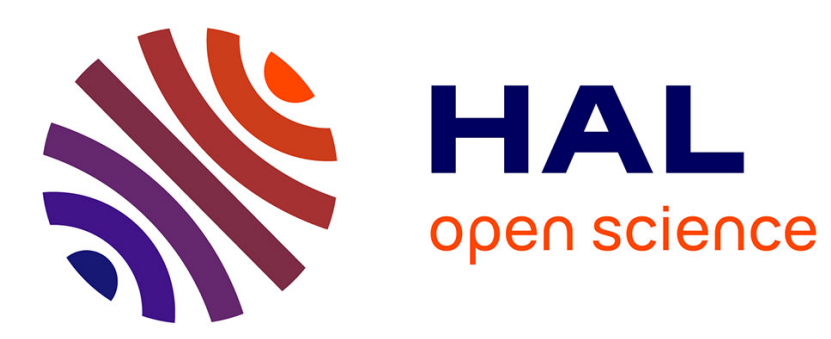

\title{
Detection of buried tree root samples by using geoelectrical measurements : a laboratory experiment
}

\author{
C. Zanetti, A. Weller, M. Vennetier, P. Mériaux
}

\section{To cite this version:}

C. Zanetti, A. Weller, M. Vennetier, P. Mériaux. Detection of buried tree root samples by using geoelectrical measurements : a laboratory experiment. Plant and Soil, 2011, 339 (1-2), p. 273 - p. 283. 10.1007/s11104-010-0574-0 . hal-00593712

\section{HAL Id: hal-00593712 \\ https://hal.science/hal-00593712}

Submitted on 17 May 2011

HAL is a multi-disciplinary open access archive for the deposit and dissemination of scientific research documents, whether they are published or not. The documents may come from teaching and research institutions in France or abroad, or from public or private research centers.
L'archive ouverte pluridisciplinaire HAL, est destinée au dépôt et à la diffusion de documents scientifiques de niveau recherche, publiés ou non, émanant des établissements d'enseignement et de recherche français ou étrangers, des laboratoires publics ou privés. 
Zanetti C., Weller A.,Vennetier M. and Mériaux P.(2011) Detection of buried tree root samples by using geoelectrical measurements: a laboratory experiment, Plant and Soil, 339, 1-2, 273-283 author-produced version of the final draft post-refeering

the original publication is available at http://www.springerlink.com/ DOI: $10.1007 /$ s11104-010-0574-0

\title{
Detection of buried tree root samples by using geoelectrical measurements: a laboratory experiment
}

\author{
Zanetti C. ${ }^{\text {ad }}$, Weller A. ${ }^{\text {b }}$, Vennetier M. ${ }^{\text {ce }}$, Mériaux $\mathrm{P}^{\text {ae }}$ \\ ${ }^{a}$ Cemagref, Hydraulics engineering and hydrology RU, 3275 route de Cézanne, CS 40061, \\ 13182 Aix-en-Provence, cedex 5, France \\ ${ }^{\mathrm{b}}$ Institut für Geophysik, Technische Universität Clausthal, Arnold-Sommerfeld-Str. 1, D- \\ 38678 Clausthal-Zellerfeld, Germany \\ c Cemagref, Mediterranean ecosystems and associated risks RU, 3275 route de Cézanne, CS \\ 40061, 13182 Aix-en-Provence, cedex 5, France \\ ${ }^{\mathrm{d}}$ Université de Provence, 29 av Robert Schuman, 13100 Aix-en-Provence, France \\ e ECCOREV FR 3098, Université Aix-Marseille, France \\ Contact: caroline.zanetti@cemagref.fr Tel: +33442669956
}

\section{Summary}

The aim of this study was to test the possibility of using geoelectrical measurements to detect and differentiate different root samples of trees rooted in dikes.

A laboratory experiment was performed to describe the electrical signal of buried freshly cut root samples according to tree species, root sample orientation and number and nature of earthfill materials.

The geoelectrical measurements were performed at the soil surface in containers. First, the electrical properties of three soil materials (gravel, sand and silt) were characterized in containers without buried roots. In subsequent steps, the root samples were buried at a depth of $0.05 \mathrm{~m}$ with different orientations: horizontally and parallel or perpendicular to the electrode array, and vertically. The complex conductivity spectra were observed in the frequency range $22.9 \mathrm{mHz}-750 \mathrm{~Hz}$. The measurements without buried roots were repeated after completing all the measurements with the roots.

In most cases, the conductivity of buried root samples increased the integral conductivity of the ground. This trend was observed mainly in gravel and sand. The parallel orientation resulted in the most significant increase of the real part of conductivity. Channelling of the current flow in the root seems to be a reliable explanation. This laboratory experiment now opens the way for in-situ measurement.

Key words: root detection, electrical measurements, induced polarisation, wood electrical properties, earth dike materials

\section{Introduction}

Trees growing on earth dikes generate safety problems and can reduce dike durability (Mériaux and Royet 2007; Vennetier et al. 2005; Zanetti et al. 2008). Root systems can penetrate the body of the dike and generate internal and external erosion risks. Tree roots can grow to great lengths $(>10 \mathrm{~m})$, thicknesses (5 to 30 $\mathrm{cm}$ in diameter) and depths (more than $4 \mathrm{~m}$ ). On flood protection dikes, root systems often take up the entire depth and width of the dike (Mériaux et al. 2006). Many studies have presented results on root systems on river banks, forest and cultivated soils and on mountains (Abernethy and Rutherfurd 2001; Danjon et al. 2008; Doussan et al. 1998; Dupraz et al. 1999; Fitter 2005; Stokes 2002; Stokes et al. 1996) but there are few references relating to root systems in dikes in the literature. Moreover, poplar (Populus Sp.) and willow (Salix Sp.) root characteristics are well known (Barsoum 2001; Karrenberg et al. 2003; Lite and Stromberg 2005) unlike those of black locust (Robinia pseudo acacia), maple (Acer Sp.), ash (Fraxinus Sp.) and oak (Quercus Sp.) which are very common on earth dikes.

Until now, the only solution for acquiring precise knowledge of a root system has been to excavate it or to remove the earth around it with water or air at high pressure. However, these solutions are destructive for both trees and dikes, time consuming and quite expensive. They cannot always be implemented due to safety reasons, particularly on dikes with a permanent head. Many protocols for studying and measuring properties of uprooted trees have been published (Bischetti et al. 2005; Danjon and Reubens 2008; Doussan et al. 1998; Fitter 2005; Gärtner and Denier 2006; Khuder et al. 2007; Pagès 1996). However, attempting to describe large undisturbed underground root systems very precisely is difficult. Non-destructive techniques such as ground penetrating radar (Butnor et al. 2001; Cermak et al. 2000; Hruska et al. 1999; Stokes et al. 1999; Wielopolski et al. 1999) and electrical tomography (Al-Hagrey 2007; Heeraman et al. 1997; Petersen and Al-Hagrey 2009) or a combination of these different tools (Amato et al. 2008; Nadezhdina and Cermak 2003; Zenone et al. 2008) have been used. Radar is not adapted as clayey material strongly attenuates the electromagnetic signal and coarse fragments generate numerous echoes.

Electrical resistivity tomography using multi-electrode arrays on the surface or in small boreholes can be successfully applied to generate images of root zones reflecting their spatial variability and to quantify their 
biomass (Amato et al. 2008; Amato et al. 2009; Petersen and Al-Hagrey 2009) or to study the water flow in soil and plants (Pagès et al. 2000). Other applications of electrical resistivity tomography using ring electrode arrays around a trunk aim at a detailed investigation of living trees (Al-Hagrey 2006; Nicolotti et al. 2003; Weihs et al. 1999). The resulting horizontal cross-sections of the conductivity distribution can be used to monitor the sap flow and to recognise decay processes in the trunk.

The investigation of an entire root system by electrical measurements is not realistically conceivable due to soil heterogeneity, seasonal variations of water content and sap flows and different properties of wood according to species and root dimensions. However, in the framework of ensuring dike safety, it should be useful to at least assess the direction, length and depth of the main roots at affordable costs, and in particular determine whether certain roots cross through the entire dike body.

The spectral induced polarisation (SIP) method is an extension of the conventional geoelectrical method. The phenomenon of polarisation of the ground was discovered by Conrad Schlumberger (1920) during his first geoelectrical direct current measurements. He noticed that the slow decay of the voltage measured between two potential electrodes could not be completely explained by the inertia of the pointer of galvanometers as they were used in the 1920s. The capacitive behaviour of the ground causes charging when the electric circuit is closed and discharging when current flow is switched off. This phenomenon, which is known in the discipline of electrochemistry as electrode polarisation, occurs when a transition between electronic and electrolytic conduction takes place. To enable current flow, a chemical reaction has to commence that hinders the current flow and results in the appearance of an overvoltage. When the current flow is switched off, the overvoltage degrades. If a sinusoidal alternating current is used, induced polarisation (IP) can be observed by a frequency dependence of the resistivity amplitude or by a phase shift between the injected current signal and the resulting voltage signal. The strength of polarisation can be expressed by the frequency effect that characterises the comparative change of the conductivity amplitude which is measured at two different frequencies. The extent of the phase shift can also be an applicable indicator for the strength of the polarisation effect. Generally, the complex electrical conductivity, which is described either by amplitude and phase angle or by a real (in-phase) and an imaginary (out-of-phase) component, varies with frequency. A complete characterisation of the electrical behaviour of a material can only be achieved by investigating the behaviour of the complex electrical conductivity over a wide frequency range. The SIP method yields both the spectra of conductivity amplitude and phase shift in a predefined frequency range. Higher frequencies, especially in field measurements, are affected by electromagnetic coupling effects. For lower frequencies, the increasing time expense marks a limit. IP phenomena of inorganic matter are caused either by metallic mineral particles in a rather poorly conducting matrix or by differences in the ion concentrations in the pore space and at the interface between matrix and pore space (Weller et al. 2000). IP effects may also be observed in the presence of organic material. Schleifer et al. (2002) and Weller et al. (2006) reported the successful application of SIP for identifying wooden relics in peat bogs. The polarisation effect of wood is caused by differences in the mobility of ions at cell membranes that hinder the electrolytic current flow and result in a separation of charge carriers of different polarity (polarisation). Laboratory investigations on a variety of wood samples have shown strong variations in the strength of polarisation depending on sample orientation, species and distance from the trunk (Martin 2009a; Weller et al. 2006). Martin (2009b) describes the application of complex resistivity tomography on living trees that integrates IP effects in tomographic measurements. Laboratory investigations on infected wood samples have shown that beside the conductivity amplitude the phase shift is also altered by certain wood diseases. Up to now, SIP investigations on root samples have not been reported.

The aim of this study was to characterize root samples of trees commonly found on dikes in various materials. Since we foresaw difficulties in carrying out a field experiment due to uncontrolled factors, we started with tests using the SIP method in the laboratory under controlled conditions. The experiment allowed describing the electrical signal of buried tree root samples according to sample orientation, number and burying depth and to the type of embedding dike material.

\section{Material and methods}

\section{Origin of root samples and characterisation}

Thirty six samples, $35 \mathrm{~cm}$ in length with complete structure (wood and bark), were selected on stumps (30 - 50 years old) extracted from Loire river dikes (France) in October 2008. The species studied were those most common on French dikes: poplar (Populus hybrida), black locust (Robinia pseudoacacia), oak (Quercus robur), ash (Fraxinus excelsior), maple (Acer negundo) and willow (Salix alba). Three samples were chosen in two diameter classes for each species: 3-4 and 6-7 cm (Figure 1). Samples were kept in hermetic plastic bags in a refrigerator until the beginning of the experiment for ten days after their extraction from the dikes to preserve their water content and electrical properties.

First, the conductivity of all the samples was determined by electrical measurements using an instrument operating at a frequency of $4.3 \mathrm{~Hz}$ to investigate the variation and the dependence on water content and sample 
Zanetti C., Weller A.,Vennetier M. and Mériaux P.(2011) Detection of buried tree root samples by using geoelectrical measurements: a laboratory experiment, Plant and Soil, 339, 1-2, 273-283

author-produced version of the final draft post-refeering

the original publication is available at http://www.springerlink.com/ DOI: 10.1007/s11104-010-0574-0

diameter. For each sample, two nails, spaced at $0.1 \mathrm{~m}$, were knocked into the bark and two others were nailed into each side of the heartwood (Figure 2). The geometric factor considers the area of cross-section of the samples and the distance of the potential electrodes.

The water content of each root sample was estimated by the difference between fresh and dry weight. Fresh weight was measured before the experiments in the laboratory. Dry weight was measured after drying in an incubator at a temperature of $50^{\circ} \mathrm{C}$ for five days.

Figure 1: Some of the large root samples used for the experiments.

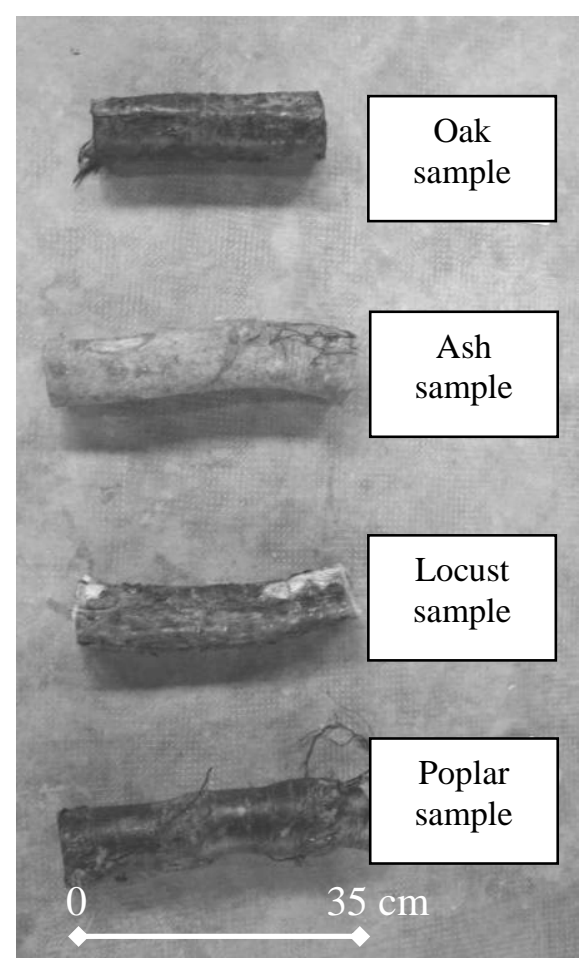

Figure 2: Example of electrical measurements on two large root samples

\section{Preparation of samples and containers}

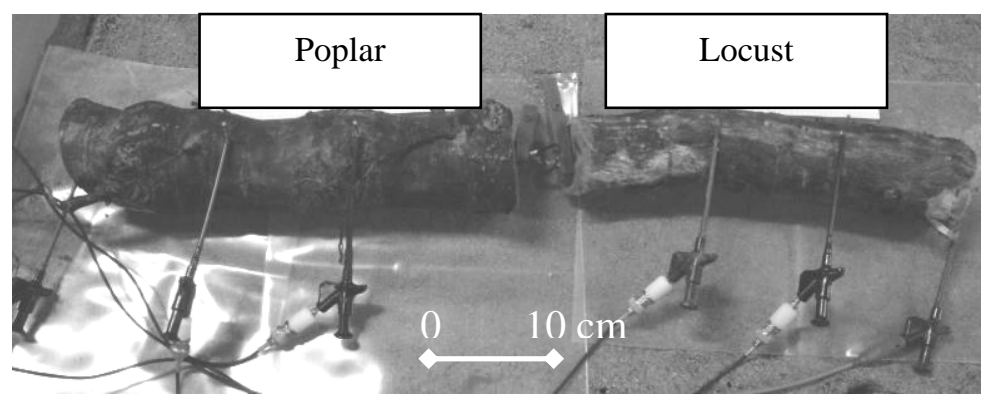

Large plastic containers $\left(1.1 \mathrm{~L}\right.$ x $0.9 \mathrm{~W}$ x $\left.0.6 \mathrm{D} \mathrm{m}^{3}\right)$ were filled with three types of dike material extracted from local quarries: silt (U), sand (S) and gravel $(\mathrm{G})$. Materials were put in containers with a tractor. Layers of approximately $20 \mathrm{~cm}$ were added and compacted with a shovel. Large containers were used to avoid edge effects during the measurements. Each box was filled with $0.5 \mathrm{~m}^{3}$ of material, weighing approximately $1000 \mathrm{~kg}$. The containers were placed inside a shed in order to guarantee nearly constant temperature and moisture conditions during the experiment.

\section{Characterisation of the material in the containers}

For each type of material, we measured the grain size distribution (by humid and dry sieving, mesh sieve of 1 $\mathrm{mm}$ to $80 \mu \mathrm{m}$ - Standard NF P 94-056) then sedimentation analyses (by measuring particles concentration with a densitometer - Standard NF P 94-057), the water content (by gravimetric method - Standard NF P 94-050) (Table 1 and Figure 3). Gravel are composed by more than $50 \%$ of pebble, sand by more of $50 \%$ of sand and silt by more of $50 \%$ of silt. Complex electrical conductivity spectra were investigated in a frequency range from 22.9 $\mathrm{mHz}$ to $750 \mathrm{~Hz}$.

\section{Measurements of complex conductivity}

The simultaneous occurrence of electrical conduction and dielectric displacement leads to the definition of an effective conductivity $\sigma^{*}$ (Olhoeft 1985; Weller et al. 2000). This complex quantity with frequency-dependent real part $\sigma$ and imaginary part $\sigma^{\prime \prime}$ includes conduction as well as polarisation phenomena and is given by

$$
\sigma^{*}(\omega)=\sigma^{\prime}(\omega)+i \sigma^{\prime \prime}(\omega)
$$


Zanetti C., Weller A.,Vennetier M. and Mériaux P.(2011) Detection of buried tree root samples by using geoelectrical measurements: a laboratory experiment, Plant and Soil, 339, 1-2, 273-283

author-produced version of the final draft post-refeering

the original publication is available at http://www.springerlink.com/ DOI: $10.1007 /$ s11104-010-0574-0

with $\omega$ being the angular frequency and $i$ the imaginary unit. The commonly measured quantities conductivity amplitude $\left|\sigma^{*}\right|$ and phase angle $\varphi$ are related to real and imaginary part of conductivity according to the following expressions:

$$
\left|\sigma^{*}\right|=\sqrt{\left(\sigma^{\prime}\right)^{2}+\left(\sigma^{\prime \prime}\right)^{2}}
$$

and

$$
\tan \varphi=\frac{\sigma^{\prime}}{\sigma^{\prime}}
$$

The commonly measured conductivity amplitude and phase values can be converted into the real and imaginary parts of conductivity according to the following relations:

$$
\sigma^{\prime}=\left|\sigma^{*}\right| \cos \varphi
$$

and

$$
\sigma^{\prime}=\left|\sigma^{*}\right| \sin \varphi .
$$

The SIP measurements were performed at the surface of soil in containers in an inverse Wenner configuration with an electrode spacing of $0.1 \mathrm{~m}$ (Figure 4). Complex conductivity spectra were observed in a low frequency range between $22.4 \mathrm{mHz}$ and $750 \mathrm{~Hz}$ using a SIP Fuchs equipment (Radic Research, Germany). First, the electrical properties of the soil material in all the containers were characterized without buried root samples and the spectra of a selected single large sample $(6-7 \mathrm{~cm}$ in diameter) of the species poplar, locust, oak and ash were investigated using the electrode geometry shown in Figure 2. The resulting complex conductivity spectra of the four different root species are displayed in Figure 7. The values of both real and imaginary part of conductivity at a frequency of $1.43 \mathrm{~Hz}$ are compiled in Table 3.

In subsequent steps, the root samples were buried with their upper margin at a depth of $0.05 \mathrm{~m}$ in different orientations: (a) parallel to the electrode array (longitudinal, Figure 5), (b) perpendicular to the electrode array (transversal, Figure 6), and (c) vertically. One or three samples (laid next to each other) of each species (poplar, locust, oak and ash) were used. The measurements without buried roots were repeated after completing all the measurements with the roots. The spectra acquired before and after the root experiments showed a slight increase in the conductivity level caused by watering of the electrodes in order to lower their contact resistance. The values measured before and after the root experiments were averaged to obtain a reference level.

Figure 3: Grain size distribution curves of the materials in the six containers.

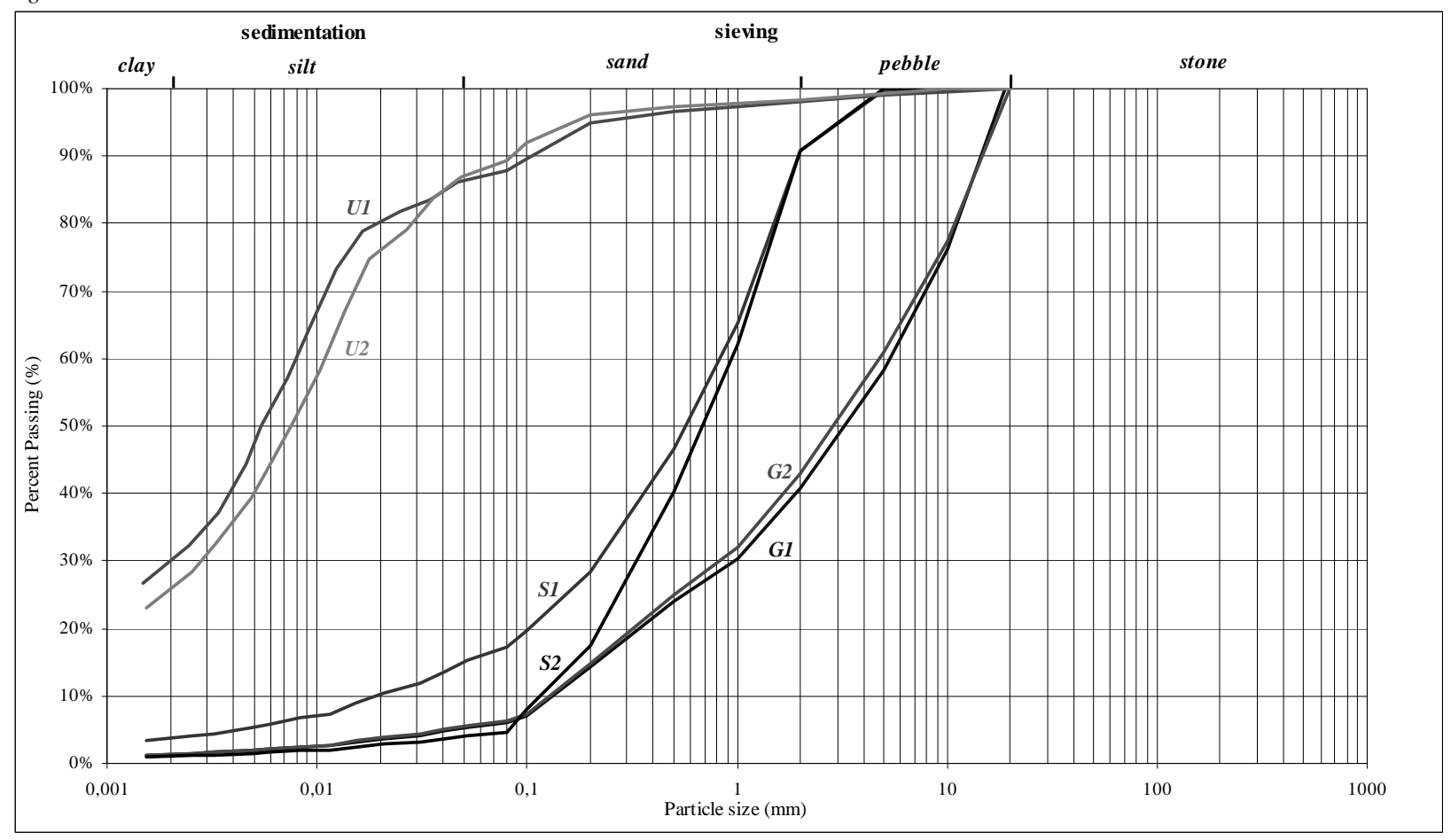


Zanetti C., Weller A.,Vennetier M. and Merriaux P.(2011) Detection of buried tree root samples by using geoelectrical measurements: a laboratory experiment, Plant and Soil, 339, 1-2, 273-283 author-produced version of the final draft post-refeering

the original publication is available at http://www.springerlink.com/ DOI: 10.1007/s11104-010-0574-0

Table 1: Water content, grain size distribution and electrical conductivity of the materials in the containers at $1.46 \mathrm{~Hz}$

\begin{tabular}{|c|c|c|c|c|c|c|c|}
\hline \multicolumn{2}{|l|}{ Material name } & G1 & G2 & S1 & $\mathbf{S 2}$ & U1 & $\mathbf{U 2}$ \\
\hline \multicolumn{2}{|c|}{ Material water content (\%) } & 5,1 & 5,2 & 6 & 6,5 & 14,6 & 15,6 \\
\hline \multicolumn{8}{|c|}{ Granulometry / sedimentology } \\
\hline & Stone $>20 \mathrm{~mm}(\%)$ & 0 & 0 & 0 & 0 & 0 & 0 \\
\hline & Pebble > 5 mm (\%) & 59 & 58 & 9 & 9 & 2 & 1 \\
\hline & Sand > $50 \mu \mathrm{m}(\%)$ & 36 & 37 & 75 & 87 & 11 & 11 \\
\hline & Silt > $2 \mu \mathrm{m}(\%)$ & 4 & 4 & 12 & 3 & 57 & 62 \\
\hline & Clay < $2 \mu \mathrm{m}(\%)$ & 1 & 1 & 4 & 1 & 30 & 26 \\
\hline \multicolumn{8}{|c|}{ Conductivity in $\mathrm{mS} / \mathrm{m}$} \\
\hline Real part & & 1.527 & 1.625 & 1.484 & 1.256 & 7.560 & 8.141 \\
\hline Imaginary part & & 0.00554 & 0.00572 & 0.00894 & 0.00850 & 0.0245 & 0.0285 \\
\hline
\end{tabular}

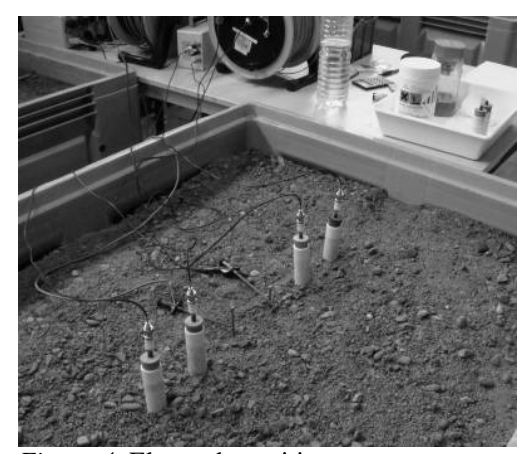

Figure 4: Electrode positions at the soil surface in a container.

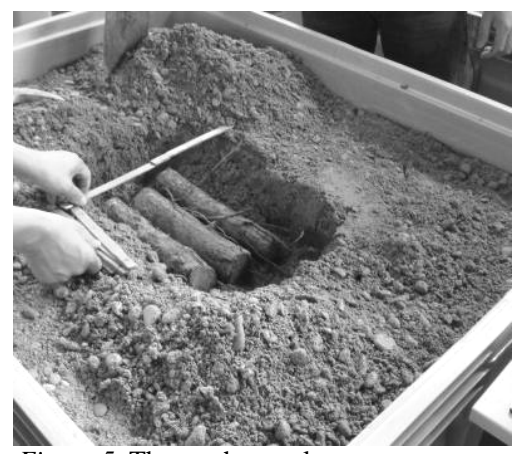

Figure 5: Three ash samples in longitudinal orientation.

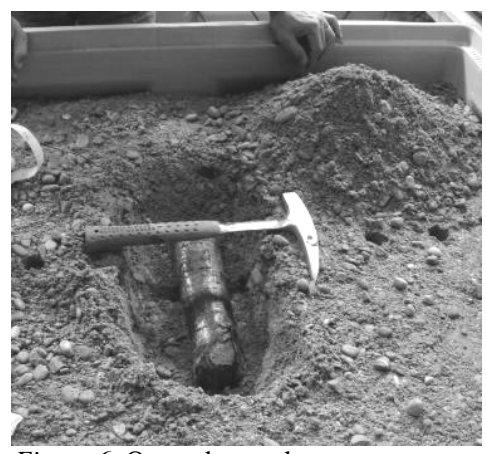

Figure 6: One oak sample in transversal orientation.

\section{Results}

The conductivity of root samples varied according to diameter and species (Tables 2 and 3). Willow and poplar exhibited the highest mean conductivity, maple and oak gave intermediate values while ash gave the lowest ones. For locust, a considerable difference between samples of smaller (3-4 cm diameter) and larger (6-7 cm diameter) diameters could be observed. Whatever the species, a good correlation between conductivity and water content was seen $\left(\mathrm{r}^{2}=0.87\right.$ and 0.58 for respectively large and small samples).

As the imaginary part of conductivity is a good indicator of the membrane polarisation effect in wooden material (Weller et al. 2006), Table 3 suggests that polarisation was strongest for poplar, followed by ash. Locust and oak were characterized by low polarisation effects.

Table 2: Water content and mean conductivity (with standard error) of root samples of different species.
\begin{tabular}{|l|c|c|cc|cc|}
\hline \multirow{2}{*}{ Species } & Diameter & \multicolumn{2}{|c|}{ Water content (\%) } & \multicolumn{3}{c|}{ Mean Conductivity $(\mathrm{mS} / \mathrm{m})$} \\
\cline { 2 - 7 } & $3-4 \mathrm{~cm}$ & $6-7 \mathrm{~cm}$ & $3-4 \mathrm{~cm}$ & $6-7 \mathrm{~cm}$ \\
\hline Ash & 49.33 & 51.32 & 10.54 & $+/-0.77$ & 12.75 & $+/-0.19$ \\
\hline Locust & 65.01 & 59.05 & 23.85 & $+/-2.99$ & 12.99 & $+/-1.52$ \\
\hline Maple & 63.09 & 60.45 & 23.34 & $+/-4.88$ & 19.13 & $+/-1.15$ \\
\hline Oak & 51.94 & 52.22 & 19.86 & $+/-1.77$ & 15.78 & $+/-3.58$ \\
\hline Poplar & 61.22 & 62.29 & 46.93 & $+/-11.42$ & 26.30 & $+/-4.86$ \\
\hline Willow & 75.63 & 80.59 & 38.84 & $+/-6.33$ & 62.00 & $+/-22.89$ \\
\hline
\end{tabular}

Table 3: Real and imaginary parts of conductivity at $1.46 \mathrm{~Hz}$ of four root samples.

\begin{tabular}{|l|c|c|}
\hline & Complex conductivity at $1.46 \mathrm{~Hz}$ in $\mathrm{m} / \mathrm{m}$ \\
\hline Poplar & Real part & Imaginary part \\
\hline Locust & 20.4 & 0.424 \\
\hline Ash & 15.2 & 0.118 \\
\hline Oak & 12.6 & 0.265 \\
\hline
\end{tabular}

The grain size distribution curves of the two gravel and the two silt containers respectively were close to each other, as were their water contents. Consequently, their electrical properties were similar in each pair of 
Zanetti C., Weller A.,Vennetier M. and Mériaux P.(2011) Detection of buried tree root samples by using geoelectrical

measurements: a laboratory experiment, Plant and Soil, 339, 1-2, 273-283

author-produced version of the final draft post-refeering

the original publication is available at http://www.springerlink.com/ DOI: $10.1007 /$ s11104-010-0574-0

containers. The sand samples exhibited slightly different grain size distributions with a higher proportion of clay and silt in container S1. This result was in agreement with the higher values of both the real and imaginary parts of conductivity in this container. Regarding the electrical properties of the material, only small differences between the gravel and sand were observed. Whereas the real part of the conductivity can be estimated by conductivity amplitude, the imaginary part of the conductivity is closely related to polarisation phenomena. The slightly higher conductivity amplitude of gravel may be caused by lower porosity. The imaginary part of conductivity reflects the increase of specific internal surface with decreasing average grain size (Börner et al. 1996; Weller et al. 2010).

In most cases, the buried wood increased conductivity, particularly in gravel and sand because the higher conductivity of buried root samples increased the integral conductivity of the ground. The orientation of root samples in parallel with the electrode array resulted in the most significant increase of the real part of conductivity.

Table 4 summarises the results of all the experiments. A conductivity ratio was determined considering the measurements with and without buried root samples at a frequency of $1.46 \mathrm{~Hz}$. Regarding the longitudinal samples in gravel, the highest increase of the real part of conductivity (ratio $=1.795$ ) was observed for poplar, followed by oak (1.503), ash (1.406) and locust (1.352). In sand, a slightly different order of ratios was obtained; the strongest effect was again caused by the poplar root sample. For oak and ash, the use of three instead of one root sample slightly increased the effect. Since the contrast in conductivity between wood and silt was lower, the effect of root samples on the real part of conductivity was reduced.

The imaginary part of conductivity was closely related to polarisation phenomena. The investigation of soil material showed weak polarisation effects for gravel and sand. The polarisation was stronger for silt. The imaginary part of the conductivity was higher when root samples were buried in the soil in most of our experiments and for the whole frequency range investigated. This increase depended on the soil type, the species and orientation of the root samples. The spectra of the four root species, which are displayed in Figure 7, show a moderate frequency dependence. The real part of conductivity increases with rising frequency. The imaginary part of conductivity reveals a more complicated behaviour that depends on the root species. A local maximum at $0.2 \mathrm{~Hz}$ is observed for the ash sample. The ash and locust samples are characterised by a continuous increase with frequency. The largest values of imaginary part of conductivity are observed for the poplar sample. The strong increase at frequencies $>10 \mathrm{~Hz}$, which is observed for all samples, may be attributed to electromagnetic coupling effects.

The spectra of buried poplar roots show a clear maximum of imaginary part of conductivity close to $1 \mathrm{~Hz}$. A considerable difference with the response of the embedding material was observed around this frequency. The longitudinal orientation resulted in a strong effect reaching a multiplication factor of 9.8 in gravel. The measurable effects in sand and silt were still considerable for both longitudinal and transversal orientations. In comparison with poplar, all the other species exhibited only weak to moderate effects. For ash and oak in longitudinal orientation, the response was more than doubled in gravel (Table 4).

Table 4: Conductivity ratio between measurements with and without buried root samples for both the real part and the imaginary part of conductivity at $1.46 \mathrm{~Hz}$.

\begin{tabular}{|c|c|c|c|c|c|c|c|}
\hline \multirow{2}{*}{ Species } & $\begin{array}{c}\text { Samples } \\
\text { orientation }\end{array}$ & \multicolumn{2}{|c|}{ Gravel } & \multicolumn{2}{|c|}{ Sand } & \multicolumn{2}{c|}{ Silt } \\
\cline { 3 - 8 } & transversal & 0.935 & 1.494 & 0.934 & 1.337 & 0.904 & 1.322 \\
\hline \multirow{4}{*}{ Ash } & 3 x transversal & 1.144 & 1.680 & - & - & - & - \\
\cline { 2 - 8 } & longitudinal & 1.406 & 2.125 & 1.144 & 1.718 & 0.785 & 1.111 \\
\cline { 2 - 8 } & 3 x longitudinal & 1.533 & 2.942 & - & - & - & - \\
\cline { 2 - 8 } & vertical & - & - & - & - & 1.097 & 1.179 \\
\hline \multirow{3}{*}{ Locust } & transversal & 1.079 & 1.422 & 1.343 & 1.697 & 1.183 & 1.355 \\
\cline { 2 - 8 } & Iongitudinal & 1.352 & 1.729 & 1.505 & 2.099 & 1.005 & 1.211 \\
\hline \multirow{4}{*}{ Oak } & transversal & 1.022 & 2.000 & 1.068 & 1.370 & 1.046 & 1.577 \\
\cline { 2 - 8 } & 3 x transversal & 1.237 & 2.974 & - & - & 0.958 & 1.286 \\
\cline { 2 - 8 } & longitudinal & 1.503 & 3.701 & 1.224 & 1.683 & 1.064 & 1.106 \\
\cline { 2 - 8 } & 3 x longitudinal & 1.528 & 4.066 & - & - & - & - \\
\cline { 2 - 8 } & vertical & - & - & - & - & 1.283 & 1.115 \\
\hline \multirow{2}{*}{ Poplar } & transversal & 1.353 & 7.448 & 1.164 & 3.151 & 1.318 & 3.367 \\
\cline { 2 - 8 } & longitudinal & 1.795 & 9.807 & 1.699 & 4.861 & 1.337 & 5.307 \\
\hline
\end{tabular}


Zanetti C., Weller A.,Vennetier M. and Mériaux P.(2011) Detection of buried tree root samples by using geoelectrical

measurements: a laboratory experiment, Plant and Soil, 339, 1-2, 273-283

author-produced version of the final draft post-refeering

the original publication is available at http://www.springerlink.com/ DOI: $10.1007 /$ s11104-010-0574-0

\section{Discussion}

As with all other geophysical methods, detectability depends on contrast in the relevant physical property. The higher the contrast in electrical conductivity between the roots and the embedding material, the stronger the resulting signals in the electrical survey. Considering the conductivity of the soil and root samples in Tables 1 and 3, it becomes obvious that gravel and sand provide good conditions for root detection. Conversely, the electrical conductivity of silt material is close to that of the root samples. Consequently, the roots will hardly change the integral conductivity and will remain undetected.

The experiment with buried roots samples has shown that the measured conductivity greatly depends on the orientation of the samples, tree species and embedding material. Buried root samples generally increase the amplitude of conductivity. The strongest effect was observed with root samples parallel to the electrode array. Other orientations lead to weaker effects. The differences observed for the tree species investigated are significant. Poplar roots give the most significant signal in all the materials. The detection of oak and locust roots may be more difficult and the identification of ash roots was impossible under these experimental conditions. The conductivity increase caused by the root samples may be explained by a current channelling in the wooden root material. Since the number of root samples for each species was limited, it is not possible to generalise the results. Root size and status at the time of sampling (water content, sap flow) have to be considered.

Besides the real part of conductivity, which can be approximated by the conductivity amplitude, the imaginary part of conductivity was assumed to provide better potential for root detection. Regarding the lowest value measured on the root samples $(0.115 \mathrm{mS} / \mathrm{m}$, Table 3$)$ and highest value measured on the soil samples $(0.0285$ $\mathrm{mS} / \mathrm{m}$, Table 1) a minimum ratio of 4 can be expected. This contrast proved to be sufficient to cause a reliably increased signal for most measurements of the imaginary part of conductivity. The conductivity ratios compiled in Table 4 show considerable variability as a function of tree species and sample orientation, leading to conclusions similar to those in the case of conductivity amplitude. Longitudinal orientation and poplar roots yield the strongest indication. The differences between species could be explained by the macroscopic character of the wood. In semi-ring porous woods (oak and locust), the pores are more numerous in young wood. The more regular distribution of the pore size in diffuse porous woods (poplar and ash) leads to a stronger polarisation effect (Figure 8).

The measured conductivity was also affected by differences in compaction and water content and not only by the type, size and orientation of root samples. Most spectra of the imaginary part of conductivity showed a steep increase towards higher frequencies. Considering that frequencies higher than $100 \mathrm{~Hz}$ are not suitable for field experiments, because measurements are distorted by electromagnetic coupling effects, lower frequencies should be chosen. Our experiment has shown that a frequency between $1 \mathrm{~Hz}$ and $10 \mathrm{~Hz}$ is a good choice. On the one hand, a SIP survey will be more time-consuming if lower frequencies are included. On the other hand, electromagnetic coupling effects are still negligible. A closer look at the complex conductivity spectra of root and soil samples that should be investigated in the lab will show whether a sufficient contrast in the electrical properties between root and soil material is observed in the selected frequency interval.

There are two types of dikes: flood protection river dikes and canal dikes. River dikes were mostly built using materials extracted from the river channel. The fine-grained sediments extracted from flood plains (fine sand, silt and clay) ensure a low permeability of the dike body. The narrow but impervious river dikes have to withstand intermittent flooding events. Most canal dikes have been built during the last 50 years. They are very large and are constructed with coarse materials (sand and gravel) in the core and at the land side of the dike structure to drain the permanent water charge. Dike environments are far more complex. The geometry and structure of the dike to be investigated has to be considered. Seasonal variations of temperature and water content severely affect the conductivity of both dike material and roots. We may conclude from our experiment that a conventional geoelectrical survey that measures only conductivity amplitude will probably fail to detect roots if the dike body consists mainly of silt or clay material.

Our study must be considered only as a first step in the development of a non-destructive method for root detection in dikes. The experiments were performed under favourable conditions in the laboratory with root samples embedded in homogeneous material. Inhomogeneity of the dike material, lateral and vertical changes in water content and compaction pose a challenge for the geoelectrical survey at real dikes. Size and depth of the root fragments are major factors that influence the detectability. Larger roots close to the surfaces can be more easily identified than small fragments at a greater depth. Only extensive tests at different dikes will provide the experience to draw reliable conclusions on the detectability of roots. 
Zanetti C., Weller A.,Vennetier M. and Mériaux P.(2011) Detection of buried tree root samples by using geoelectrical measurements: a laboratory experiment, Plant and Soil, 339, 1-2, 273-283

author-produced version of the final draft post-refeering

the original publication is available at http://www.springerlink.com/ DOI: 10.1007/s11104-010-0574-0

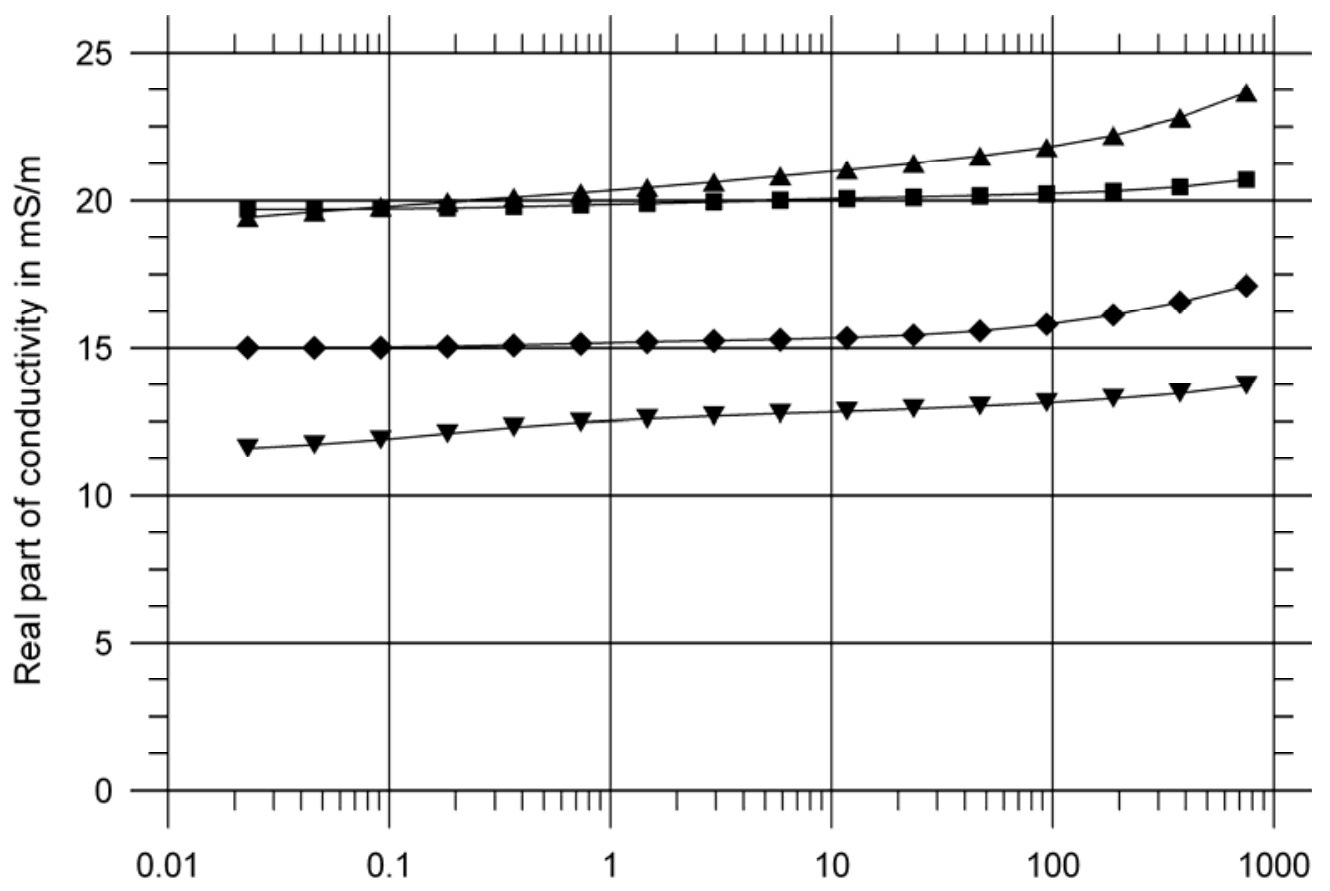

Frequency in $\mathrm{Hz}$

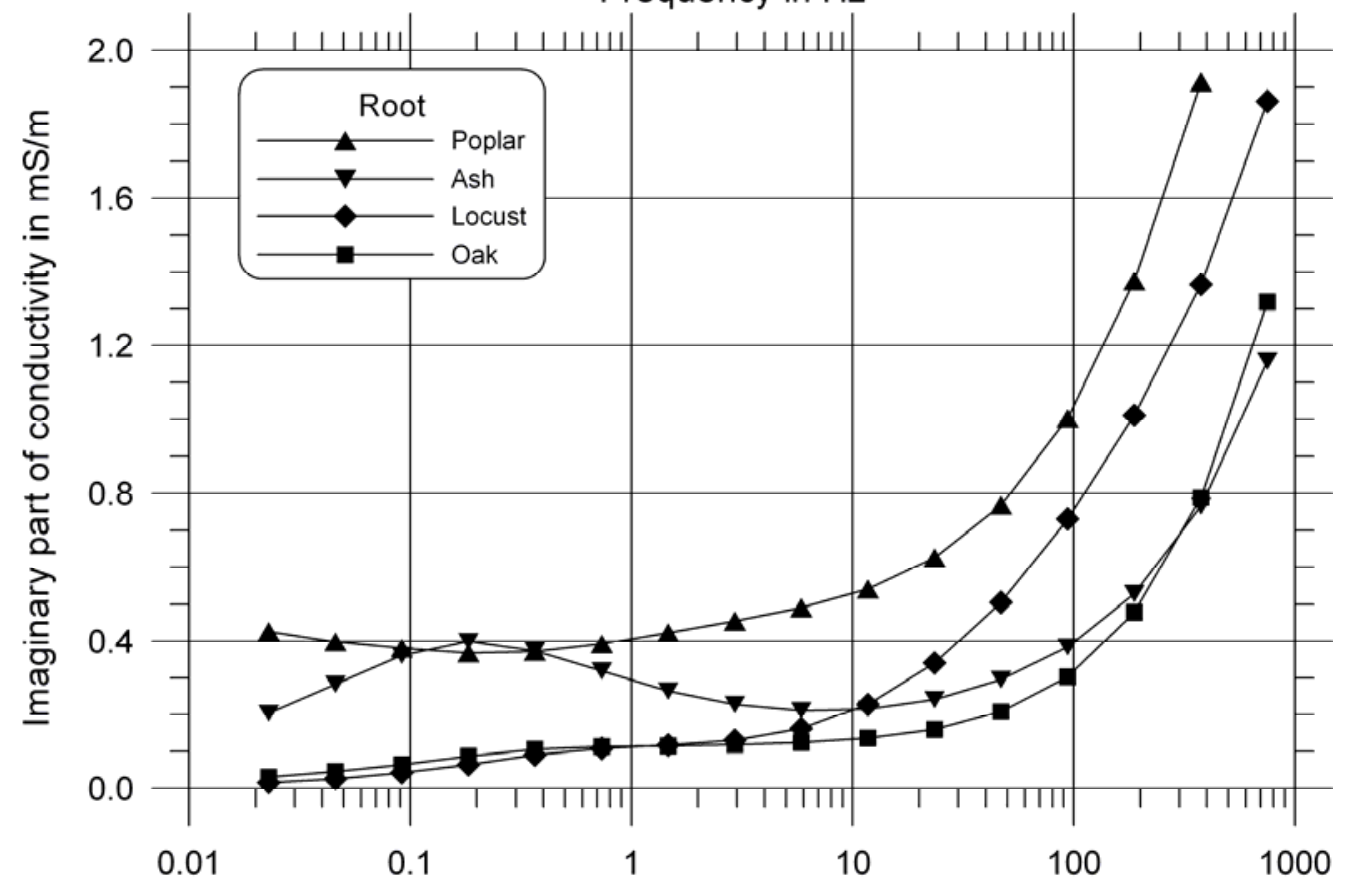

Frequency in $\mathrm{Hz}$

Figure 7: Complex conductivity spectra of four root samples in a frequency range from $22.4 \mathrm{mHz}$ to $750 \mathrm{~Hz}$. 


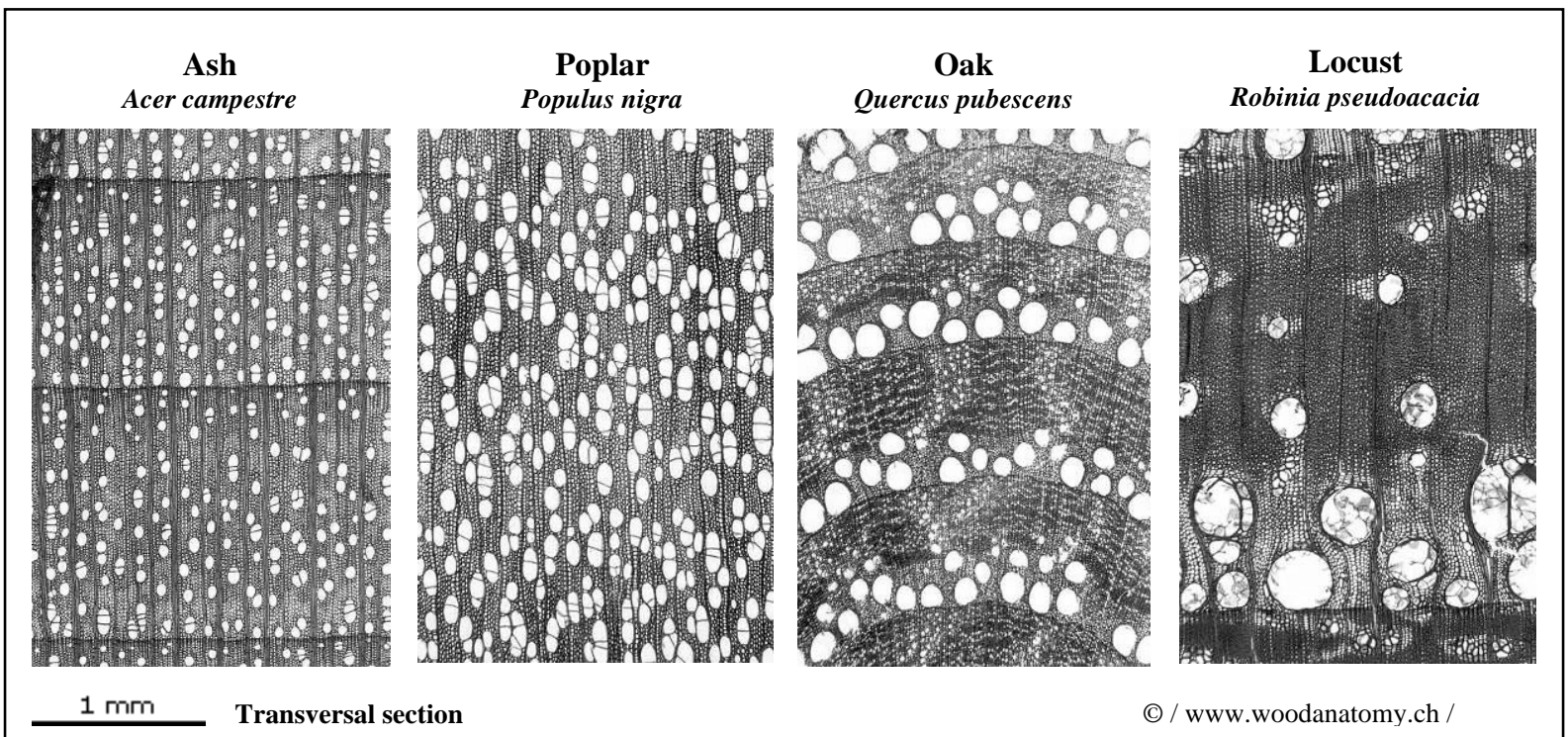

Figure 8: Macroscopic wood anatomy for the four species studied. Diffuse distribution of pores for ash and poplar, and ring pores for oak and locust (Schweingruber 1982).

\section{Conclusion}

Regarding the results of our experiments, there is a good chance that a field procedure including the measurement of the imaginary part of conductivity would provide useful signals for the detection of extended root networks in dikes. The spectral induced polarisation method (SIP) provides complex conductivity data. In comparison with a conventional geoelectrical survey, SIP is a slow and expensive method that has not been included in routine dike inspections up to now (Palma-Lopes et al. 2008). Demonstrating the possibility of detecting the depth and extent of root networks in inhomogeneous dikes requires thorough investigation: calibration tests should be conducted on dikes with known root structures and under different conditions and in different seasons. Periods of active sap flows should be favourable. Such investigations could also be performed in other contexts where root structures and soil conditions are well known.

\section{Acknowledgments}

We thank Pham Quy Ngoc and Nguyen Trong Vu (Ph.D. students at Clausthal University of Technology) for their help during the laboratory experiments and LERMI (Cemagref Aix en Provence) for providing the space to perform them. This study was funded by the Provence-Alpes-Côte d'Azur Region, Cemagref and the Procope Project (French Ministry of Foreign Affairs - French German collaboration). The constructive comments received from two anonymous reviewers significantly improved this manuscript.

\section{References}

Abernethy B and Rutherfurd I D (2001) The distribution and strength of riparian tree roots in relation to riverbank reinforcement. Hydrol Process 15: 36-79. (??10.1002/hyp.152??)

Al-Hagrey S (2006) Electrical resistivity imaging of tree trunks. Near Surf Geophys 4: 179-187.

Al-Hagrey S (2007) Geophysical imaging of root-zone, trunk and moisture heterogeneity. Jour Experiment Bot 58: 839-854. doi:10.1093/jxb/erl237

Amato M, Basso B, Celano G, Bitella G, Morelli G and Rossi R (2008) In situ detection of tree root distribution and biomass by multi-electrode resistivity imaging. Tree Phys 28(10): 1441-1448. doi:10.1093/treephys/28.10.1441

Amato M, Bitella G, Rossi R, Gómez J A, Lovelli S and Gomes J J F (2009) Multi-electrode 3D resistivity imaging of alfalfa root zone. Europ J Agronomy 31: 213-222. doi:10.1016/j.eja.2009.08.005

Barsoum N (2001) Relative contributions of sexual and asexual regeneration strategies in Populus nigra and Salix alba during the first years of establishment on a braided gravel bed river. Evol Ecol 15: 255-279. doi : 10.1023/A:1016028730129

Bischetti G, Chiaradia E, Simonato T, Speziali B, Vitali B, Vullo P and Zocco A (2005) Root strength and root area ratio of forest species in Lombardy - Northern Italy. Plant Soil 278: 11-22. doi:10.1007/s11104005-0605-4 
anetti C., Weller A.,Vennetier M. and Mériaux P.(2011) Detection of buried tree root samples by using geoelectrical measurements: a laboratory experiment, Plant and Soil, 339, 1-2, 273-283 author-produced version of the final draft post-refeering the original publication is available at http://www.springerlink.com/ DOI: 10.1007/s11104-010-0574-0

Börner F D, Schopper J, and Weller A (1996) Evaluation of transport and storage properties in the soil and groundwater zone from induced polarization measurements. Geophys Prospect 44: 583-601.

Butnor J, Doolittle J, Kress L, Cohen S and Johnsen H (2001) Use of ground-penetrating radar to study tree roots in the southeastern United States. Tree Phys 21: 1269-1278. doi:10.1093/treephys/21.17.1269

Cermak J, Hruska J, Martinkova M and Prax A (2000) Urban tree root systems and their survival near houses analyzed using ground penetrating radar and sap flow techniques. Plant Soil 219: 103-116.

Danjon F, Barker D H, Drexhage M and Stokes A (2008) Using three-dimensional plant root architecture in models of shallow-slope stability. Annals Bot 101: 1281-1293. doi:10.1093/aob/mcm199

Danjon F and Reubens B (2008) Assessing and analyzing 3D architecture of woody root systems, a review of methods and applications in tree and soil stability, resource acquisition and allocation. Plant Soil 303: 134. doi:10.1007/s11104-007-9470-7

Doussan C, Pages L and Vercambre G (1998) Modelling of the hydraulic architecture of root systems: An integrated approach to water absorption - Distribution of axial and radial conductances in maize. Annals Bot 81: 213-223.

Dupraz C, Simorte V, Dauzat M, Bertoni G, Bernadac A and Masson P (1999) Growth and nitrogen status of young walnuts as affected by intercropped legumes in a Mediterranean climate. Agrofor Syst 43: 71-80. doi:10.1023/A:1026499103899

Fitter A (2005) Characteristics and functions of root systems. In Plant Roots - The hidden half, Eds Y Waisel and A Eshel. pp 193-237. Marcel Dekker, New York.

Gärtner H and Denier C (2006) Application of a 3D laser scanning device to acquire the structure of whole root systems- A pilot study. TRACE - Tree Rings in Archaeology, Climatology and Ecology, 4: 288-294.

Heeraman D A, Hopmans J and Clausnitzer V (1997) Three dimensional imaging of plant roots in situ with Xray computed tomography. Plant Soil 189: 167-179. doi:10.1023/B:PLSO.0000009694.64377.6f

Hruska J, Cermak J and Sustek S (1999) Mapping tree root systems with ground-penetrating radar. Tree Phys 19 : 125-130. doi:10.1093/treephys/19.2.125

Karrenberg S, Blaser S, Kollmann J, Speck T and Edwards P J (2003) Root anchorage of saplings and cuttings of woody pioneer species in a Riparian Environment. Funct Ecol17: 170-177.

Khuder H, Danjon F, Stokes A and Fourcaud T (2007) Interactions between static and dynamic loading and their influence on acclimative growth in young trees. In International Conference on Wind and Trees, Vancouver, British Columbia, Canada.

Lite S J and Stromberg J C (2005) Surface water and ground-water thresholds for maintaining Populus-Salix forests, San Pedro River, Arizona. Biol Conserv 125: 153-167 doi:10.1016/j.biocon.2005.01.020

Martin T (2009a) Anwendung des komplexen elektrischen Widerstandsverfahrens an Eichen (Quercus spp.). In BAM Dissertationsreihe, Berlin.

Martin T (2009b) Complex resistivity (CR) of wood and standing trees. In Non-Destructive Testing in Civil Engineering, Nantes, France June 30th-July 3rd. Ed NDTCE’09. pp 963-968.

Mériaux P and Royet P (2007) Surveillance, maintenance and diagnosis of flood protection dikes - A practical handbook for owners and operators. Quae 162.

Mériaux P, Vennetier M, Aigouy S, Hoonakker M and Zylberblat M (2006) Diagnosis and management of plant growth on embankment dams and dykes. In Commission Internationale des Grands Barrages, Barcelona. pp 1-20.

Nadezhdina N and Cermak J (2003) Instrumental methods for studies of structure and function of root systems of large trees. J Exp Bot 54: 1511-1521. doi: 10.1093/jxb/erg154

Nicolotti G, Socco L V, Martinis R, Godio A and Sambuelli S (2003) Application and comparison of three tomographic tomographic techniques for detection of decay in trees. Jour Aboricul 29: 66-78.

Olhoeft G R (1985) Low-frequency electrical properties. Geophysics 50: 2492-2503.

Pagès L (1996) Modeling Root system architecture. In Plant roots: The hidden half, Eds Y Waisel and A Eshel. pp 359-382. Dekker New York.

Pagès L, Doussan C and Vercambre G (2000) An introduction on below-ground environment and resource acquisition, with special reference on trees. Simulation models should include plant structure and function. Ann For Sci 57: 513-520. doi:10.1051/forest:2000138

Palma-Lopes S, Djedai M, Nicaise J, François D, Mériaux P and Royet P (2008) Suivi d'infiltration dans une digue en terre par imagerie de résistivité électrique: expérimentation sur le canal des Houillères de la Sarre. In Dixièmes Journées AGAP- Qualité, Aix en Provence 21-22 octobre 2008. Ed GEOFCAN. pp 29-32.

Petersen T and Al-Hagrey S (2009) Mapping root zones of small plants using surface and borehole resistivity tomography. Leading Edge 28: 1220-1224. doi:10.1190/1.3249778

Schleifer N, Weller A, Schneider S and Junge A (2002) Investigation of Bronze Age plankway by spectral induced polarisation. Archaeol Prospect 9: 243-253. doi:10.1002/arp.194

Schlumberger C (1920) Etude sur la prospection électrique du sous-sol: Gauthier-Villar et Cie, Chap. VIII, 7072. 
Zanetti C., Weller A.,Vennetier M. and Mériaux P.(2011) Detection of buried tree root samples by using geoelectrical measurements: a laboratory experiment, Plant and Soil, 339, 1-2, 273-283

author-produced version of the final draft post-refeering

the original publication is available at http://www.springerlink.com/ DOI: 10.1007/s11104-010-0574-0

Schweingruber F H (1982) Anatomie microscopique du bois. Institut Fédéral de Recherche Forestière, Zurich. $220 \mathrm{p}$.

Standard NF P 94-056 : Analyse granulométrique des sols - Méthode par tamisage à sec après lavage, Norme Européenne NF EN ISO, Mars 1996.

Standard NF P 94-057 : Analyse granulométrique des sols - Méthode par sédimentation, Norme Européenne NF EN ISO, Mai 1992.

Standard NF P 94-050 : Détermination de la teneur en eau pondérale des matériaux - Méthode par étuvage, Norme Européenne NF EN ISO, Septembre 1995.

Stokes A (2002) Biomechanics of tree root anchorage. In Plant roots: the hidden half, Eds Y Waisel and A Eshel. pp 175-186.

Stokes A, Ball J, Fitter A, Brain P and Coutts M (1996) An experimental investigation of the resistance of model root systems to uprooting. Annals Bot 78: 415-421.

Stokes A, Fourcaud T, Hruska J, Cermak J, Nadyezhdhina N, Nadyezhdin V and Praus L (1999) An evaluation of different methods to investigate root systems architecture of urban trees in situ: I ground penetrating radar. J Arboric 28: 2-10.

Vennetier M, Ripert C, Chandioux O, Mériaux P and Doirat G (2005) Gestion de la végétation des digues et berges sous contrainte de sécurité. Ing EAT 3-14.

Weihs U, Dubbel V, Krummheuer F and Just A (1999) The electrical resistivity tomography - a promising technique for detection of coloured heartwood on standing beech trees (in German). Forst und Holz 54: 166-170.

Weller A, Frangos W and Seichter M (2000) Three-dimensional inversion of induced polarization data from simulated waste. Journal of Applied Geophysics 44: 67-83.

Weller A, Nordsiek S and Bauerochse A (2006) Spectral induced polarisation - a geophysical method for archaeological prospection in peatlands. Journal of Wetl Archaeology 6: 105-125.

Weller A, Slater L, Nordsiek S and Ntarlagiannis D (2010) On the estimation of specific surface per unit pore volume from induced polarization: A robust empirical relation fits multiple datasets. Geophysics 75, no. 4 (in press).

Wielopolski L, Hendrey G, Daniels J and Mc Guigan M (1999) Imaging tree root systems in situ (GPR). In Brookhaven National Laboratory. pp 1-5. Upton NY USA.

Zanetti C, Vennetier M, Mériaux P, Royet P, Dufour S and Provansal M (2008) L'enracinement des arbres dans les digues en remblai: étude des systèmes racinaires et impacts sur la sécurité des ouvrages. Ing EAT 53: 49-67.

Zenone T, Morelli G, Teobaldelli M, Fischanger F, Matteucci M, Sordini M, Armani A, Ferrè C, Chiti T and Seufert G (2008) Preliminary use of ground-penetrating radar and electrical resistivity tomography to study tree roots in pine forests and poplar plantations. Funct Plant Biol 35: 1047-1058. 